\title{
The Stonehenge Riverside Project: exploring the Neolithic landscape of Stonehenge
}

\author{
Mike Parker Pearson', Joshua Pollard², Colin Richards 3 , Julian Thomas 3 , \\ Chris Tilley 4 and Kate Welham 5 \\ 1 Department of Archaeology, University of Sheffield; 2 Department of Archaeology and Anthropology, \\ University of Bristol, Julian.Thomas@manchester.ac.uk; 3 School of Arts, Histories and Cultures, \\ University of Manchester; 4 Department of Anthropology, University College London; \\ 5 School of Conservation Sciences, University of Bournemouth
}

\begin{abstract}
The Stonehenge Riverside Project is a collaborative enterprise directed by six academics from five UK universities, investigating the place of Stonehenge within its contemporary landscape. In this contribution, a series of novel approaches being employed on the project are outlined, before the results of investigations at the Greater Stonehenge Cursus, Woodhenge, the Cuckoo Stone and Durrington Walls are discussed.
\end{abstract}

IZVLEČEK - Stonehenge Riverside Project je skupen projekt, ki ga vodi šest profesorjev s petih univerz Združenega kraljestva Velike Britanije. Ukvarjamo se s položajem Stonehenga v takratni pokrajini. V prispevku predstavljamo vrsto novih pristopov, ki smo jih uporabili v projektu, kot tudi rezultate raziskav Greater Duringhton Cursus, Woodhenge in Durrington Walls.

KEY WORDS - Stonehenge; Durrington Walls; Southern Britain; monumentality; landscape

\section{Introduction: the landscape of Stonehenge}

Stonehenge is a national symbol, recognised throughout the world, and interpreted in different ways by a wide variety of constituencies, from Druids to New Age enthusiasts (Chippindale 1990) (Fig. 1). It has served as a focus for contemporary cultural and political struggles, and has a special place in popular culture and the public imagination (Bender 1998; Worthington 2004; 2005). Yet the attention that Stonehenge attracts sometimes occludes its place within a broader landscape, a World Heritage Site composed of a great many structures and deposits that built up over dozens of generations (Darvill 2005) (Fig. 2). This process arguably began with the construction of an arrangement of huge post-holes dating to the eighth millennium BC (in the earlier Mesolithic), discovered when the car-park for Stonehenge itself was constructed in 1966 (Cleal, Walker and Montague 1995.43). This clearly refutes the argument that only agriculturalists build monuments (e.g. Rowley-Conwy 2004.85), but it also potentially demonstrates the longevity of special places within this particular landscape. During the early 1980s, a very important programme of investigation was conducted by Julian Richards, under the rubric of the Stonehenge Environs Project. This combined targeted excavations with extensive field walking to identify the surface concentration of lithics (Richards 1990). The intention of this project was to place the known field monuments into a clearer chronological framework, and to identify complementary domestic and industrial activity in their immediate surroundings.

The publication of the Stonehenge Environs Project, and that of the various excavations by Gowland, Hawley, Atkinson, Piggott, Stone, and the Vatchers 
at Stonehenge itself during the course of the twentieth century (Cleal, Walker and Montague 1995) represent an unparalleled contribution to knowledge. However, for more than twenty years the pursuit of archaeological investigations on any scale within the Stonehenge landscape has been curtailed by the continuing deliberations over the future of the A303 trunk road (which runs immediately to the south of the monument). Potential options have included the possibility of running the major road through a bored tunnel, closing the stretch of the A344 road that severs Stonehenge from the Avenue which connects it to the River Avon, and establishing a visitor centre to replace the present subterranean structure beside the car-park. At present, it appears that only the improvements to visitor facilities are likely to proceed in the foreseeable future (Harris 2007). Irrespective of the view that one might take of this outcome, the effective hiatus affecting archaeological research in the Stonehenge landscape has coincided with a period of heightened debate over the character of social archaeology, particularly as it relates to the British Neolithic (e.g. Barrett 1994; Bradley 1998; Whittle 2003). As a result, until now the opportunity has not arisen to 'field trial' a variety of new ideas and approaches in the immediate context of Stonehenge. While hypotheses and arguments concerning Stonehenge have continued to be constructed, they have had to rely on existing evidence, often collected according to the research agendas of past generations.

\section{New approaches to the landscape}

The Stonehenge Riverside Project is a collaborative research initiative directed by six academic archaeologists from five different British universities. It brings a series of novel approaches to bear on the development of the Stonehenge landscape, and we can begin this contribution by outlining each. The first is a concern with what we might call the 'materiality of monuments': that is, an interest in the physicality and constituent substances involved in monument building. These issues animated a pioneering study by Parker Pearson and Ramilsonina (1998), who drew on a parallel with contemporary Madagascar to suggest that monuments constructed of timber and stone respectively may have been understood in different ways by Neolithic people. For many Malagasy communities, the human body is considered to be soft and wet at birth, maturing to greater hardness and dryness, and culminating in the exceptionally hard and dry character of the bones of the ancestral dead. Consequentially, while the living inhabit houses made of wood, whose organic character has much in common with human flesh, stone tombs and standing stones are the exclusive prerogative of the dead. In a similar way, Parker Pearson and Ramilsonina noted that while Stonehenge is distinguished by its multiple stone settings, the presence of numerous cremation burials, and a general paucity of ceramics and human remains, the much larger henge monument at Durrington Walls,

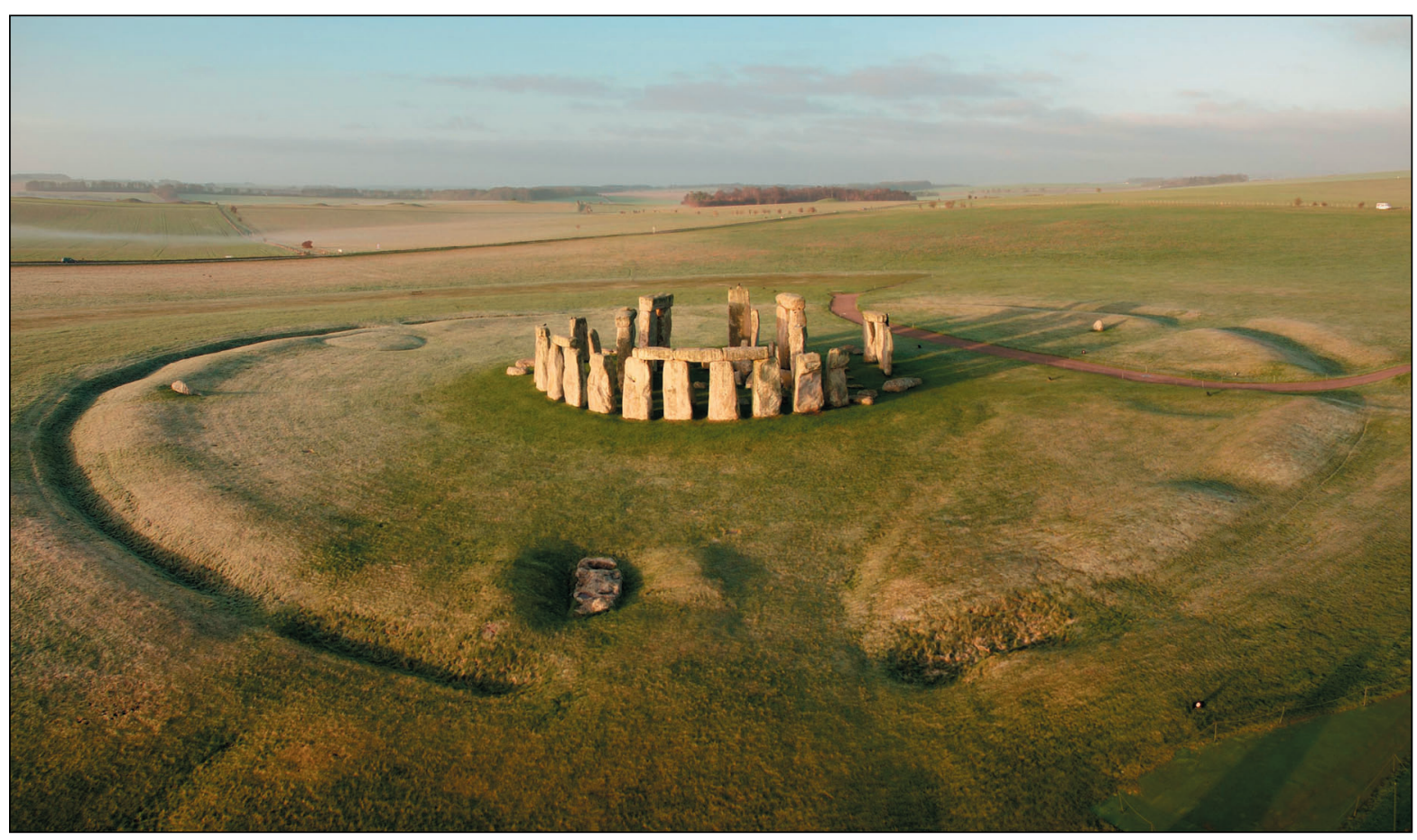

Fig. 1. Stonehenge, seen from the north-east (photo: Aerial-Cam). 


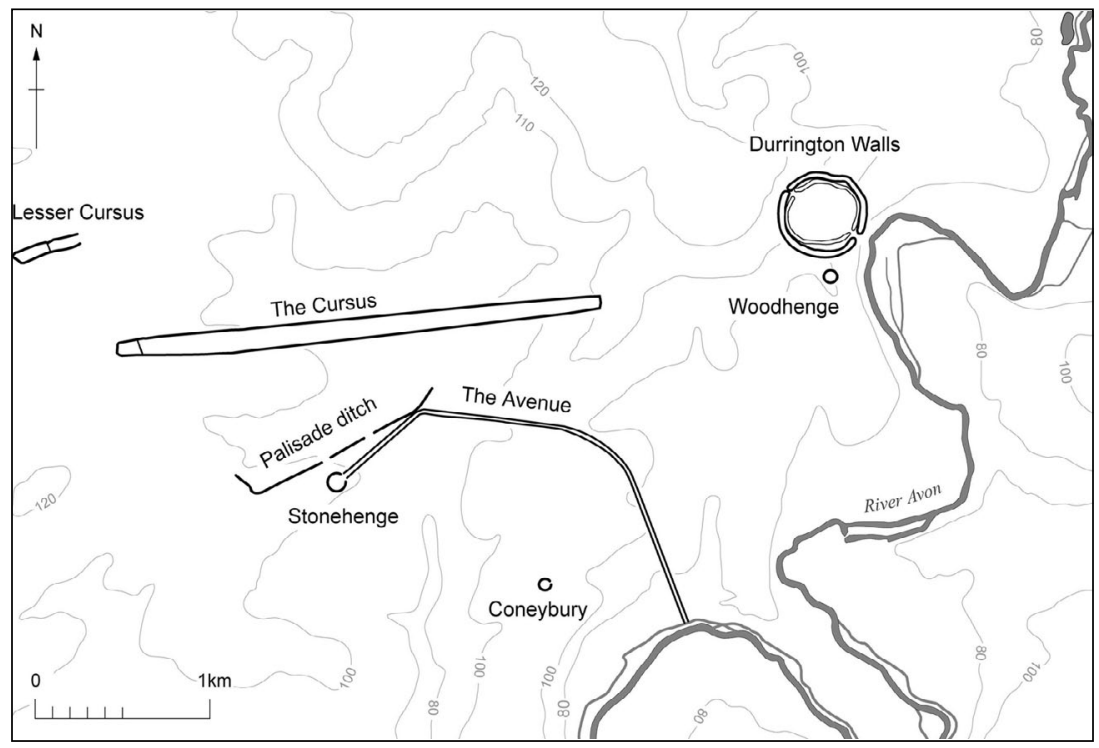

Fig. 2. Map of prehistoric monuments in the Stonehenge area (drawing: Anne Leaver).

3 kilometres to the north-east, showed a very different pattern. Here, there were multiple settings of upright timbers inside a massive earthwork enclosure, and colossal quantities of animal bones and Grooved Ware pottery (Wainwright and Longworth 1971). On this basis, Parker Pearson and Ramilsonina hypothesised that the two monuments might have been focal to two distinct areas of the landscape, reserved for the living and the dead, and linked by the River Avon. The transformation of the newly dead into ancestors might then be physically expressed through the passage downriver, from Durrington Walls to Stonehenge. Such an argument at once draws our attention to the complementarity of the two monuments, to the way that what are often

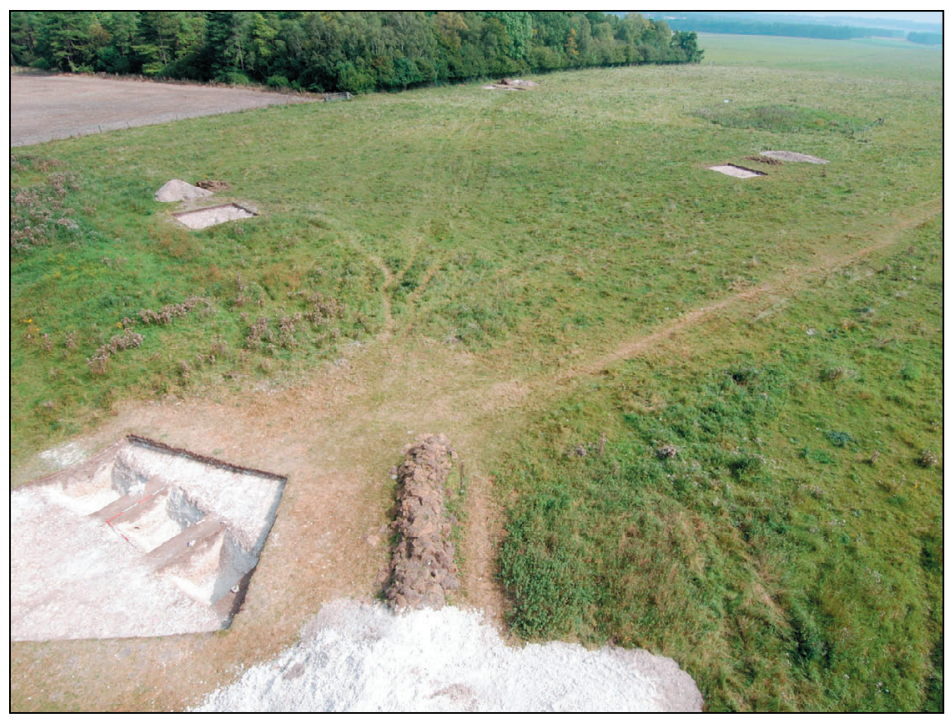

Fig. 3. The Greater Stonehenge Cursus under excavation, summer 2007 east (photo: Aerial-Cam). understood as separate structures may form parts of a single complex, and to the axial role of the River Avon within the Stonehenge landscape.

This emphasis on the material substance of monumental constructions is complemented by a concern with the construction of monuments as a collective social practice ( $R i$ chards 2004). Rather than a simple exercise in ergonomics, the creation of elaborate works like Stonehenge and Durrington Walls involved the mobilization of large numbers of people, materials, animals and food, in an enterprise that could generate prestige and fame for the builders, but which also risked shame and failure if the desired outcome was not achieved. Moreover, addressing the physical composition of monuments encourages us to think about their varying temporal qualities: the way that their decay, destruction or endurance conditions and contributes to quite different histories or biographies of place (Thomas 2004).

A second theme is provided by a new attentiveness to the disposition of materials in the archaeological record, informed by the concept of 'structured deposition'. This originated in work undertaken by two of the authors in the 1980s, re-assessing the evidence from Geoffrey Wainwright's excavations at the Durrington Walls henge, and suggesting that many of the deposits at the site had been deliberately placed, as one aspect of ritual activity ( $R i$ chards and Thomas 1984). More recently, increasingly sophisticated analyses have drawn attention to the important role of depositional practice in transforming the meaning of place, and in engendering memory (Pollard 1995; 2001). Both within monumental structures and in isolated pits dispersed across the landscape, the placement of artefacts and other materials appears to have been one of the key means by which people expressed their connection with specific locations during the British Neolithic (Garrow 2006). 


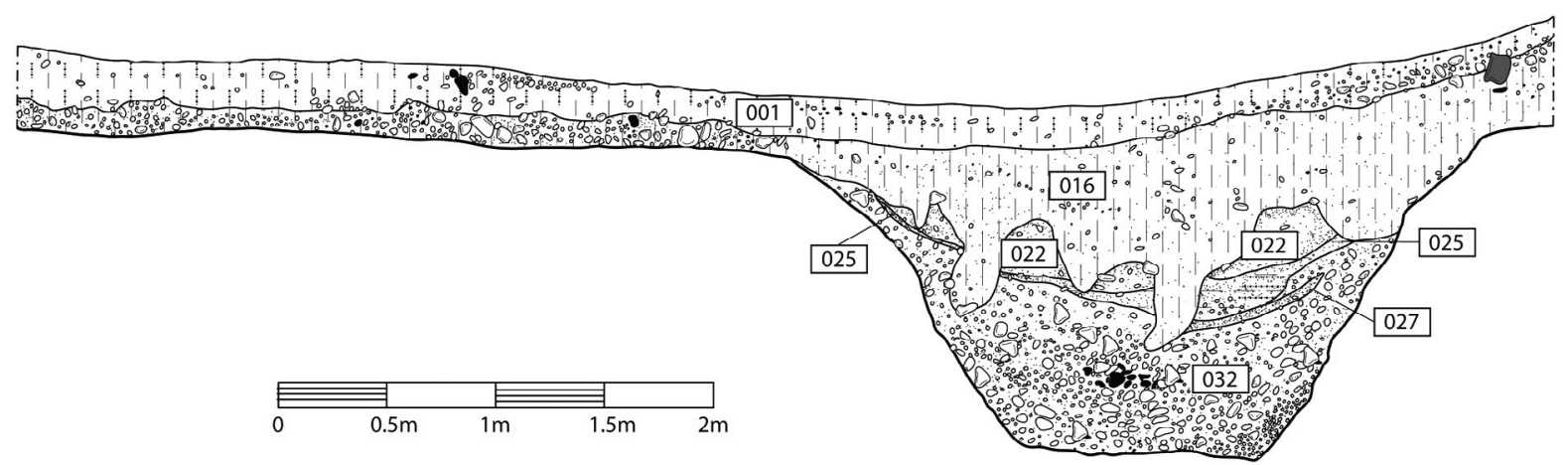

Fig. 4. Section of the Greater Stonehenge Cursus at its western terminal (drawing: Julia Roberts).

Our third preoccupation is what we might call the 'phenomenology of landscape', or an approach to field survey that stresses the experiential qualities of places and monuments (Tilley 1994). Although the area surrounding Stonehenge has been subject to exhaustive survey and mapping, from the work of Sir Richard Colt Hoare and Philip Crocker (Hoare 1810) down to the high quality investigations of English Heritage (e.g. McOmish, Field and Brown 2002), it is arguable that a concern with the way that the landscape might be engaged with from a human perspective is capable of generating fresh insights. Both in terms of the architectural organisation of specific monuments, and in relation to the wider landscape, a number of novel observations have been generated (Tilley et al. 2007). In harmony with some of the arguments already outlined, it is clear that the River Avon and the system of dry valleys with which it articulates had a fundamental role in influencing the location of a variety of structures throughout the Neolithic and Early Bronze Age. As well as delimiting areas of higher ground, the valley systems define a series of potential routes through the landscape, so that significant structures may have been positioned in such a way as to be encountered by people and their animals in the course of their daily or seasonal movements. Equally, Beacon Hill, a distinctive natural eminence formed by the intersection of the chalk with the pebble deposits of the Reading Beds, seems to be visible from or aligned upon by almost all of the Neolithic and Early Bronze Age constructions in the whole landscape, including Stonehenge itself (Tilley et al. 2007.189). While Beacon Hill possesses no upstanding prehistoric features of its own, its evident influence on the development of the monumental landscape demonstrates that 'natural' topographic features often hold great significance.

Finally, the Stonehenge Riverside Project has sought to employ a series of new field technologies, many of which have not previously been used in the Stonehenge area. As well as very large areas of GPS, magnetometer and resistivity survey, the project has made use of ground-penetrating radar, laser scanning of archaeological features, and unmanned photographic aircraft. At the Durrington Walls henge, for instance, this work has revealed two formerly unknown blocked entrances through the henge bank, and the causewayed character of the ditch, indicating that this was probably dug in sections by a series of work-gangs.

\section{Monuments as places of enduring significance}

The earliest site investigated under the aegis of the project is also the largest. The Greater Stonehenge Cursus is a linear enclosure over a mile long, which runs between the King Barrow Ridge and Fargo Ridge, immediately north of Stonehenge (Stone 1947; Christie 1963) (see Fig. 2). The Cursus is intimately associated with a series of Early Neolithic long barrows, including Amesbury 42, which runs parallel with its eastern terminal (Richards 1990. 96). However, the only radiocarbon date that has previously been derived from it falls in the mid-third millennium cal BC, in our Later Neolithic (28902460 cal BC; OxA-1403). In the summer of 2007 , excavations were able to demonstrate that this date had come from one of a series of intrusive features, which formed the first of two phases of re-cutting in the cursus ditch (Fig. 3) (Thomas et al. 2008). Clearly, the cursus was a very long-lived structure, which was repeatedly re-established over a long period of time. This was underlined by radiocarbon determinations from a piece of antler located on the bottom of the ditch at its western terminal, which calibrated to $3632-3375 \mathrm{BC}$ and $3630-3370 \mathrm{BC}$ at the $95.4 \%$ confidence level (OxA-17953 and OxA-17954) (Fig.4). This is roughly half a millennium earlier than the earliest phase of construction at Stonehenge itself, so that the cursus can be said to have had an impor- 


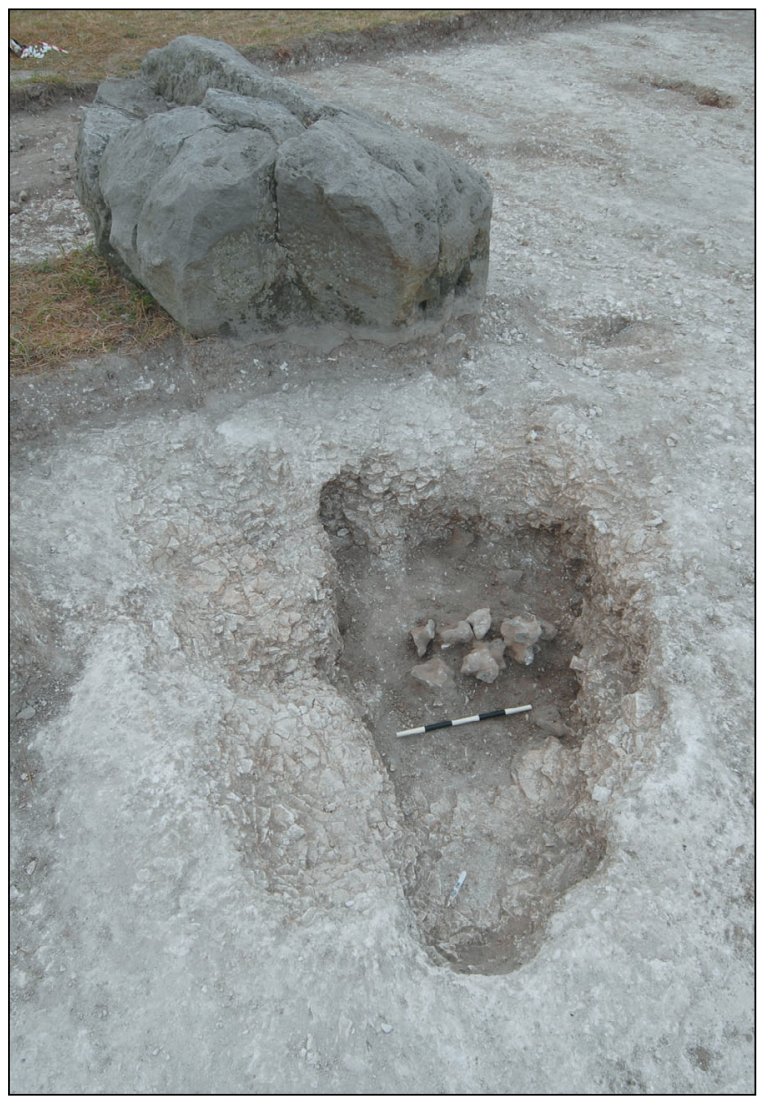

Fig. 5. The Cuckoo Stone: excavations 2007 (photo: Aerial-Cam).

tant role in structuring the landscape into which Stonehenge was placed. In the course of excavation it was also recognised that the initial laying-out of the structure involved an alignment on Beacon Hill, tying the enclosure into the local topography. Neither geophysics nor excavation could locate any internal features, and the ditches contain so little material culture that we were very lucky to recover the one piece of antler noted above. So, unlike other Neolithic structures in the area, the cursus gives little indication of having been used for ceremonial, consumption or deposition, and this supports the idea that it enclosed a venerated, sanctified or cursed area, which was set apart from the rest of the landscape.

Immediately to the east of the Cursus, and in line with its axis, excavation was conducted during 2007 at the Cuckoo Stone, a formerly upstanding sarsen monolith (Fig. 5). This is one of two isolated sarsen stones that have been investigated by the project, and both here and at the Tor Stone on Bulford Hill, the stone socket and the hole from which the stone was quarried were discovered. This is of particular importance as there has been a continuing debate in the literature over the question of whether some of the sarsens at Stonehenge could have been acquired locally, or whether they must all have been dragged from the Marlborough Downs, nearly 20 miles to the north (Stone 1924.69; Atkinson 1956.110). Evidently, we have two examples of sarsen stones recovered from the chalk of Salisbury Plain. Both the Cuckoo Stone and the Tor Stone seem to have been set up in the Neolithic, and to have formed a focus for Neolithic pits, Early Bronze Age urned cremations, and in the case of the Cuckoo Stone, a Roman shrine. So as at the Cursus we have a sense of a particular site maintaining its importance over an exceedingly long period.

The same is true of Woodhenge, the small late Neolithic enclosure just south of Durrington Walls originally excavated by Maud Cunnington in the 1920s (Cunnington 1929). Here, excavation in 2006 revealed that the bank overlay a tree-hole which had been filled with large quantities of Early Neolithic carinated bowl pottery, before being covered over by a chalk capping. Moreover, the concentric timber circles that Cunnington had excavated proved to have been succeeded by two separate phases of stone settings, again indicating a very long-lived structural sequence (Pollard and Robinson 2007. 162) (Fig. 6). In 2007, immediately to the south of Woodhenge, in an area of Bronze Age ring-ditches which had also been investigated by Cunnington,

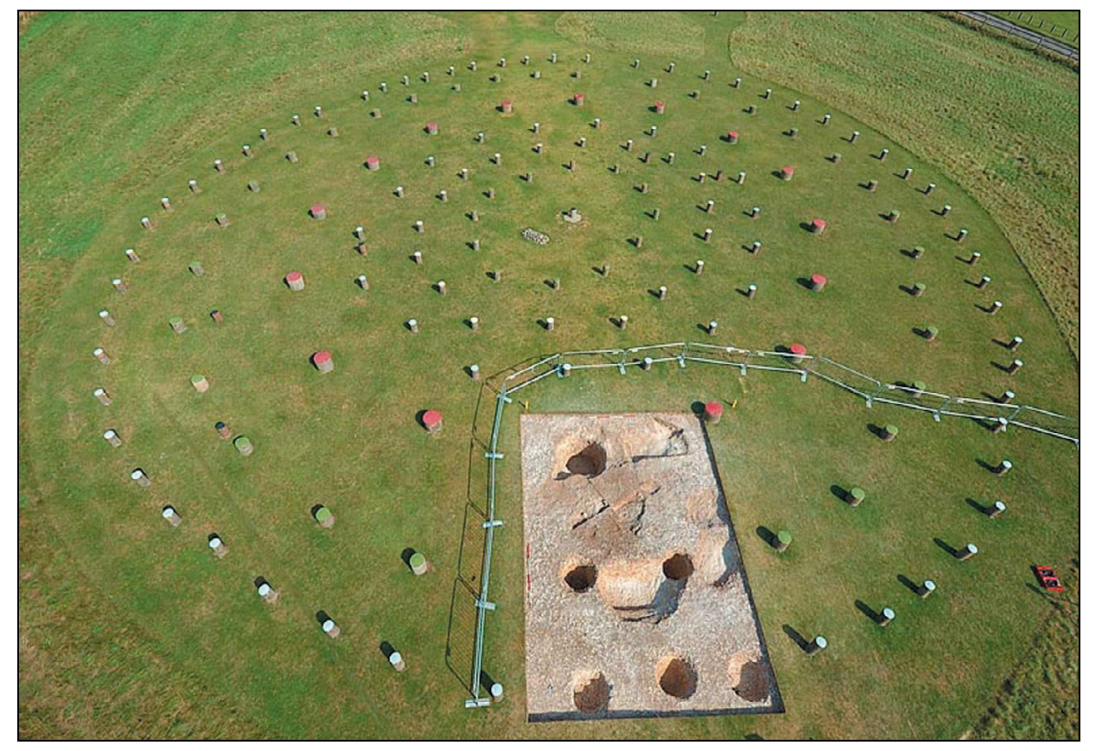

Fig. 6. Excavations at Woodhenge, 2006 (photo: Aerial-Cam). 
three separate Late Neolithic timber structures were encountered, each composed of four main uprights, with two entrance posts and, in some cases, an enclosing palisade (Fig. 7). Although these were not roofed structures, their architecture seems to relate to the small houses of the Late Neolithic Grooved Ware tradition (see below). In this respect, they are very relevant to the evidence that was recovered immediately to the north, at Durrington Walls.

\section{Durrington Walls}

Durrington Walls is the largest

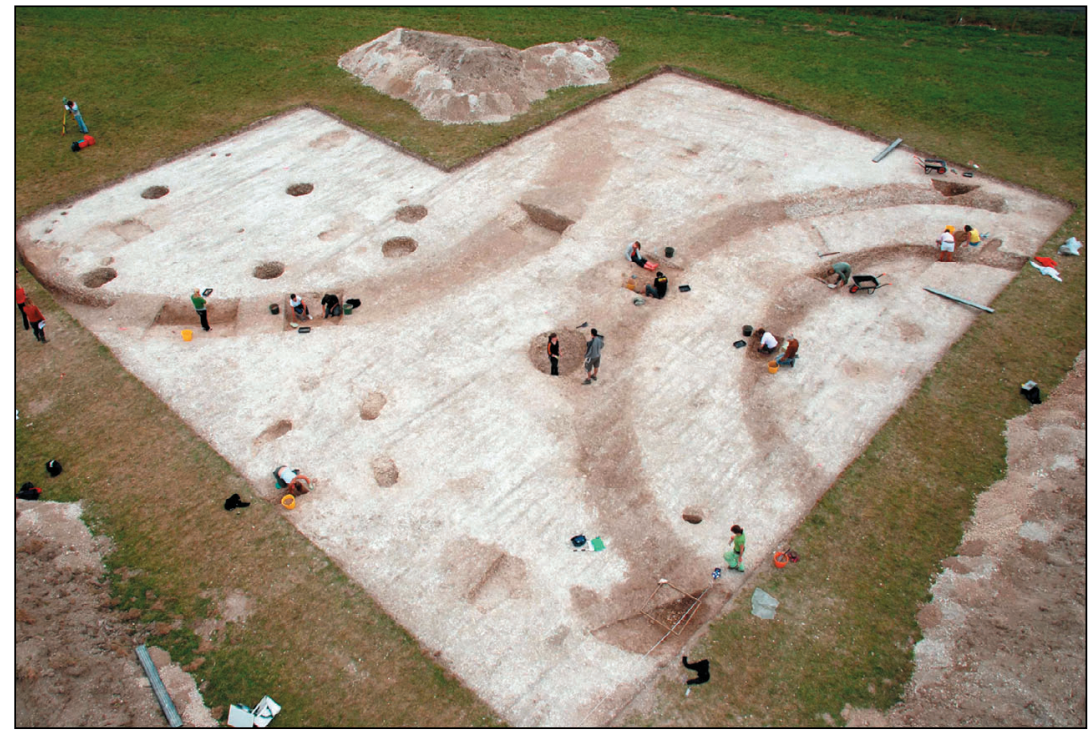

Fig. 7. Exacavation of Late Neolithic timber structures, amongst Early Bronze Age ring ditches, south of Woodhenge 2007 (photo: Aerial-Cam).

henge monument in Britain, with an overall diameter of nearly half a kilometre (Fig. 8). Henges are a type of enclosure dating to the later Neolithic, from $3000 \mathrm{BC}$ onwards, distinguished by having an external bank surrounding an internal ditch. For the most part, they are considered to have been ceremonial, and non-domestic in character, the enclosure keeping something in - or at least secluding it, rather than keeping enemies out (Wainwright 1989. 14). When Geoffrey Wainwright excavated at Durrington in 1966-7, in advance of road-building, the strip that he cut across the enclosure was the largest prehistoric excavation that had ever taken place in Britain (Wainwright and Longworth 1971; Pitts 2000.55). Wainwright's excavation revealed colossal banks and ditches and massive timber circles, and produced prodigious quantities of Grooved Ware, animals bones, and stone tools. His work transformed our understanding of the Neolithic in southern Britain but, because it was a rescue project conducted under formidable time constraints, it left a series of questions unanswered. Forty years later, new excavations conducted as part of the Stonehenge Riverside Project sought to complement the extensive work of the 1960s with a more targeted, intensive approach.

The initial decision to excavate outside of the eastern entrance of the Durrington Walls henge was based on the hope of discovering an avenue connecting the henge to the River. This would confirm the link between Durrington and Stonehenge. Just such an avenue was found in 2005 , actually a huge metalled roadway, 30 metres wide, with a bank and gully on either side, leading for 170 metres down to the river. The avenue had traces of extensive trampling down the middle, and large quantities of highly fragmented animal bones and Grooved Ware pottery scattered on either side. It was re-surfaced on two occasions, and had a line of upright sarsen stones running down one side (Parker Pearson 2007.130).

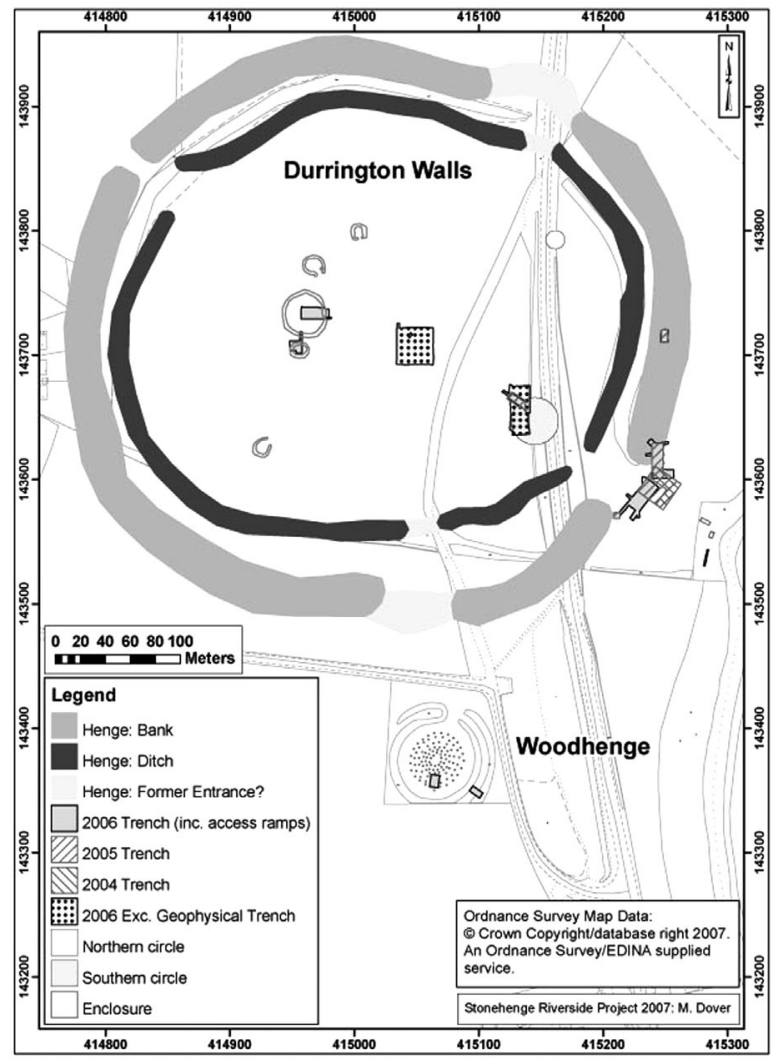

Fig. 8. Durrington Walls: areas excavated 2004-7 (drawing: Mark Dover). 


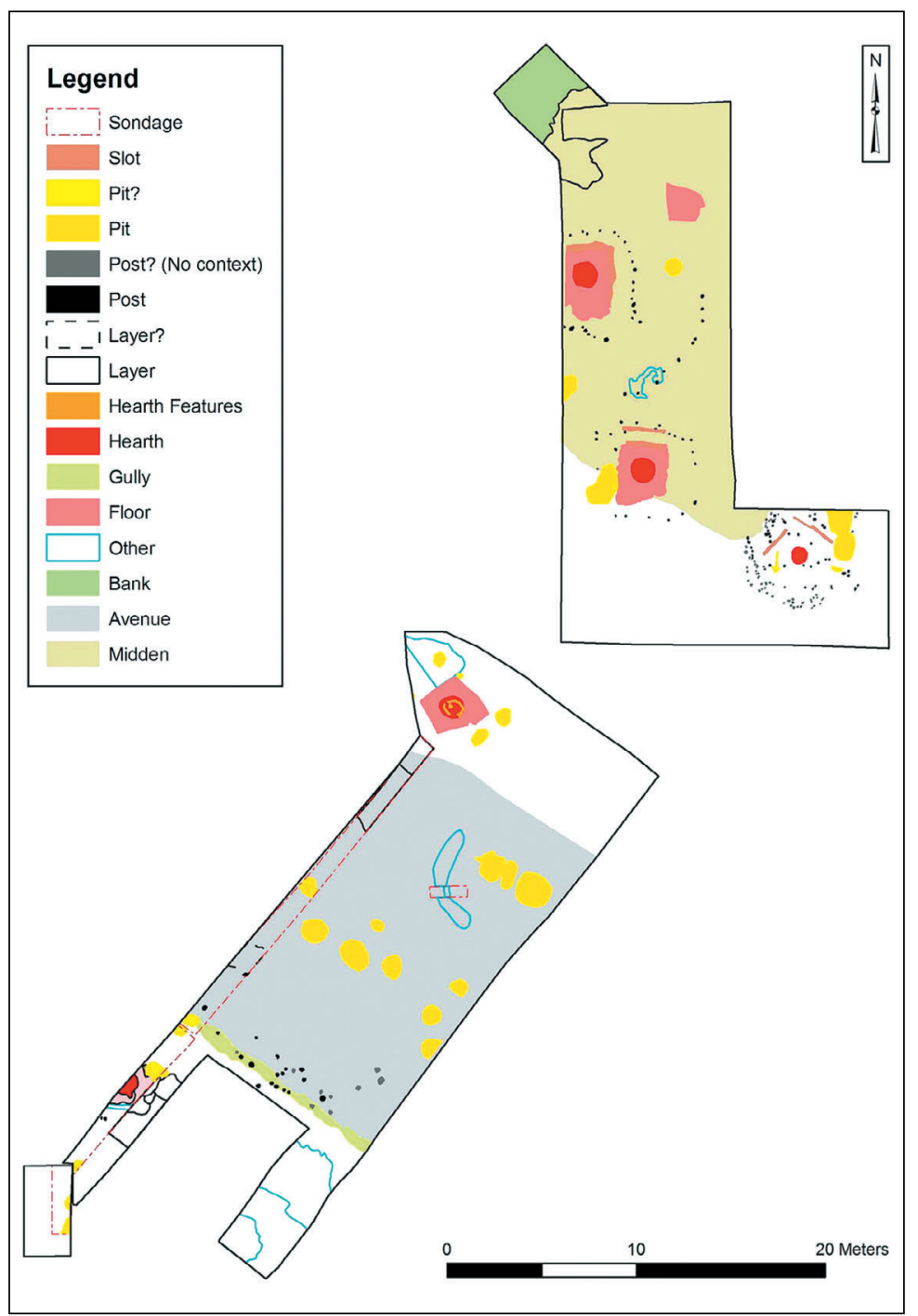

Fig. 9. Plan of excavations at the eastern entrance, Durrington Walls, 2004-7, showing the Avenue and Neolithic house floors (drawing: Mark Dover).

This last point invites comparison with the West Kennet Avenue, connected to the Avebury henge in north Wiltshire, but in the local context, it is clear that this roadway is the equivalent of the Stonehenge Avenue, linking the henge to the river, and in a way that has an astronomical alignment complementary to that at Stonehenge. The stone settings at Stonehenge face the midsummer sunrise, while the Stonehenge Avenue is aligned on the midwinter sunset; the southern timber circle inside Durrington Walls faces the midwinter sunrise, and the Durrington Avenue aligns on the midsummer sunset. The implication is that one might process from Durrington to Stonehenge at midwinter, and in the opposite direction at midsummer, passing over or through the purifying or transforming waters of the river in the process. Recent reconsideration of the radiocarbon dates from Stonehenge has demonstra- ted that the sarsen stones and the avenue can be placed in the mid-third millennium cal BC, contemporary with Durrington Walls (Parker Pearson et al. 2007.627), so we are entitled to see the two monuments as parts of a single, integrated structure.

Although the potential presence of the avenue was the initial reason for excavating at the eastern entrance, the presence of seven small houses of Late Neolithic date, clustered around the roadway (Fig. 9) was a complete surprise. Two of these were located on opposite banks of the avenue, and appear to have been open on their eastern sides, facing toward the river. Only a very few such houses have been found on the British mainland, and never as a substantial settlement, so the only real parallels are the villages of stone cellular buildings in the Orkney Isles of northern Scotland, such as Skara Brae, Rinyo and Barnhouse (Childe 1931; Childe and Grant 1947; Richards 2003). Like the Orcadian houses, the Durrington buildings have clay floors and central hearths, but their walls were of wattle and daub rather than stone (Fig. 10). Several of the houses had floor levels that had been terraced back into the hillside, and some were separated by fence-lines, against which waste materials in the form of burnt flint, flint cores and animal bones had been flung (Fig. 11). Associated with the houses were borrow pits, from which the daub had been acquired, and other pits containing dense deposits of animal bone and pottery, as well as large numbers of flint arrowheads. The buildings appear to have been abandoned with some formality: three had a single human bone deposited close to them, and two had deposits of cattle vertebrae placed into their hearths.

Several of the structures were stratified beneath the henge bank, which indicates that both the houses and at least the first phase of the avenue pre-date the construction of the bank and ditch. It is likely that the enclosure of the great natural amphitheatre of Durrington Walls may have been made at the very end of the Neolithic (at around 2500-2400 BC), and that there was a complex sequence of structures of 
various kinds that culminated in this event, and which paralleled the sequence at Stonehenge. At various points around its circumference, excavations (whether for the purposes of research or for pipe trenches) have cut through the bank, and in every case a dense spread of cultural material has been encountered, similar to that spread over the settlement area (e.g. Stone, Piggott and Booth 1954). The implication is that a Late Neolithic settlement covered the entire area covered by the henge bank, and that it was very large indeed. None the less, this settlement was clustered around a roadway leading to an enormous timber circle (see below) and was close to the group of nondomestic timber structures identified south of Woodhenge (see above), indicating that the immediate location was rather special

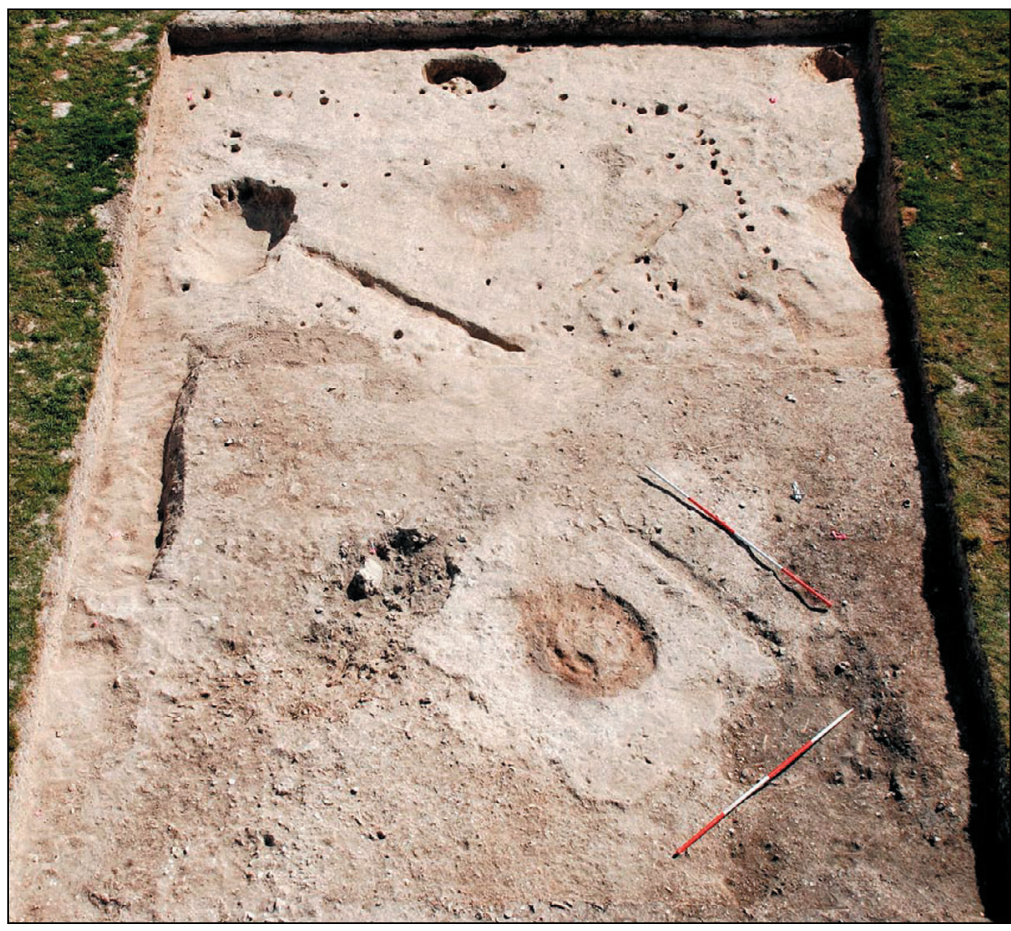

Fig. 10. Two of the house floors at the eastern entrance, Durrington Walls (photo: Aerial-Cam). even before the henge bank and ditch were constructed. It is open to question whether the huge accumulation of houses at Durrington represents a typical Late Neolithic habitation, fortuitously preserved under the combination of bank and hill-wash, and whether we should expect to find numerous such settlements in future.

There are several strands of evidence that suggest that the situation was not straightforward. Some of the anticipated signs of year-round domestic activity are missing. Despite having subjected enormous numbers of soil samples to flotation, no cereal grains or glume fragments have been recovered from the settlement area: the only cereal remains came from the surface of the avenue. This is complemented by a complete absence of grinding stones. Amongst the assemblage of 80000 pig and cattle bones, there are no neonates at all, suggesting that animals were brought to the site and not raised in the immediate area. The lithic assemblage from the settlement is dominated by transverse arrowheads, with few scrapers and knives, and no flint or stone axes. All of this suggests temporary (perhaps seasonal) rather than permanent habitation. There are very large numbers of domesticated pig bones, but some of these animals seem to have been shot with arrows and then barbequed. This does not suggest conventional culinary behaviour, and there are strong indications that periodic feasting took place (Albarella and Serjeantson 2002). An unusual proportion of the animal bones are complete and hundreds were discarded still in articulation. Tooth eruption evidence suggests that most of the pigs were killed at about nine months old, most likely in the midwinter period. Given the

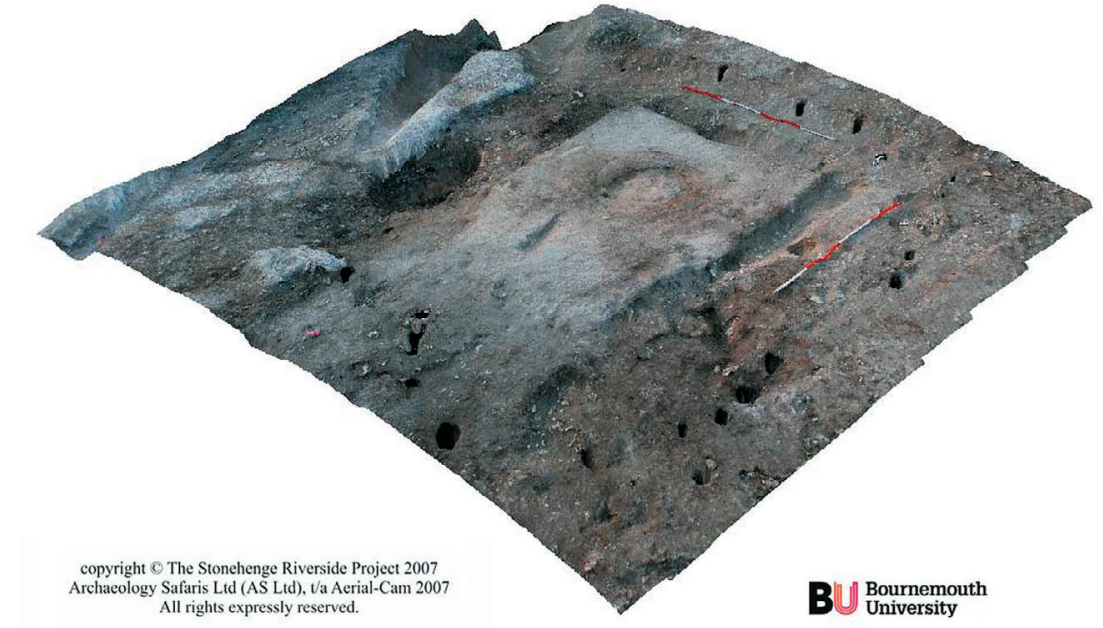

Fig. 11. Laser scan of the surface of a Neolithic house-floor, eastern entrance, Durrington Walls (image: Kate Welham/Mark Dover). 


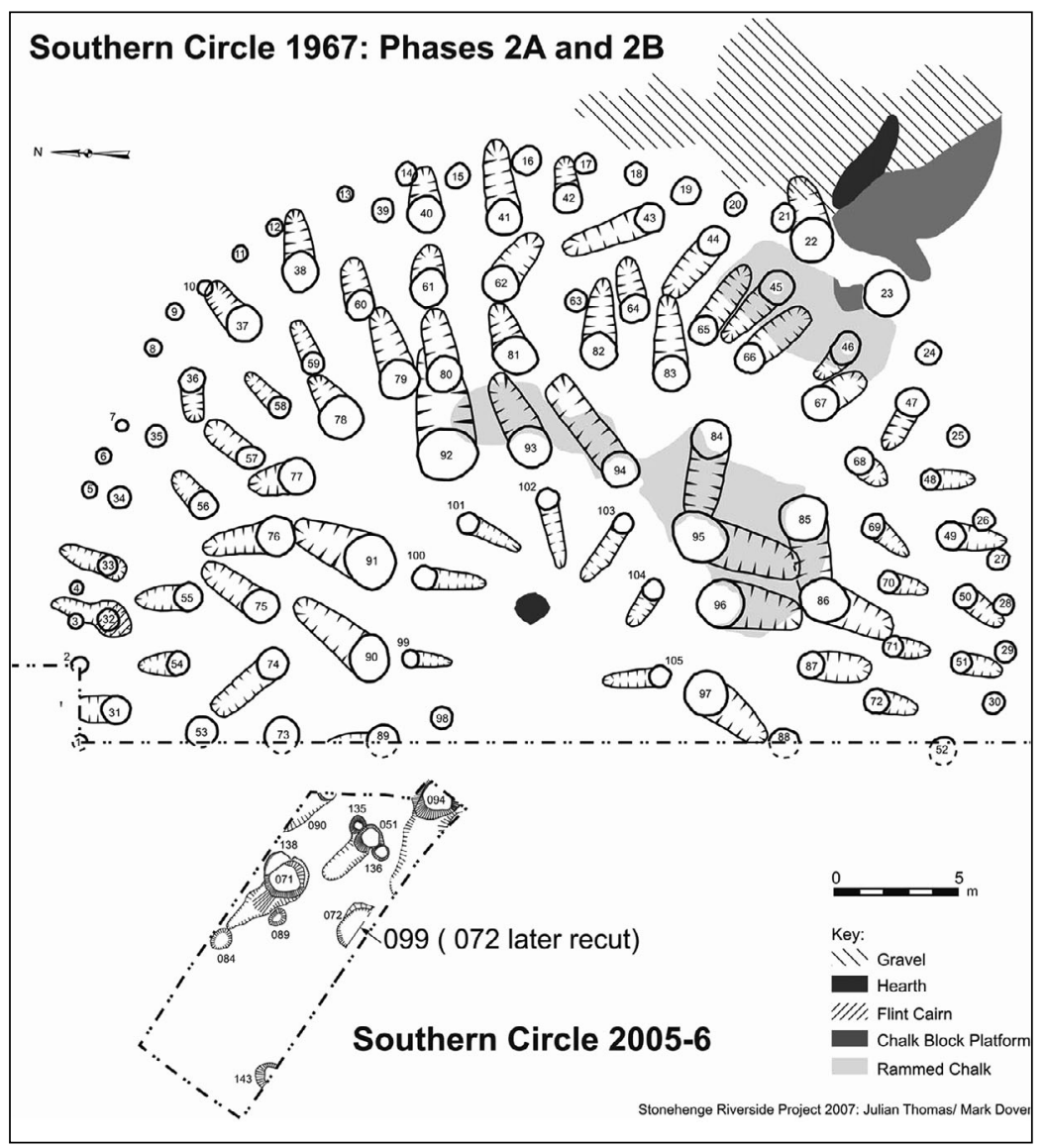

Fig. 12. The Southern Circle, Durrington Walls: plan of excavations 1967 and 2005-6 (drawing: Mark Dover).

midwinter solstice alignments at Stonehenge and at four of the Durrington timber monuments, it is likely that this was a major calendrical event. The first few radiocarbon determinations for the settlement show that it was occupied in the $26^{\text {th }}$ century BC. Some of the house floors were re-plastered up to seven times, and the inter-cutting of the borrow pits associated with each house suggests up to a dozen episodes of repair for the walls and floors. However, this might still mean that the overall inhabitation of the settlement was comparatively brief. Further radiocarbon dates may tell us whether the site served as a centre for seasonal gatherings or pilgrimage for many decades, or whether it represents a single significant episode, such as an accumulation of population to build the stone settings at Stonehenge.

\section{The Southern and Western Circles at Durring- ton Walls}

Some indication of the character of the activity at Durrington Walls is provided by a series of structures enclosed inside the henge bank and ditch further to the west. The Southern Circle was a twophase timber structure composed of six concentric rings of upright posts, $60 \%$ of which was excavated by Wainwright in 1967 (Wainwright and Longworth 1971.23) (Fig. 12). A further timber structure, the Northern Circle, was also identified in the same excavation. On its eastern side the Southern Circle intersected with a chalk and gravel platform, which we can now identify as the western extremity of the Durrington Avenue, leading down to the river. This provides a stratigraphic link that places the circle earlier than the henge bank and ditch: the timbers of the Southern Circle penetrated the surface of the avenue, but their post-holes were in some cases masked by it. Another element of the Southern Circle complex, originally identified as an enclosed midden, can now be reconsidered in the light of the discoveries at the eastern entrance. It is very likely that this represented a large, hall-sized building with a terraced floor area surrounded by stakehole-defined walls. Wainwright considered that the timber circle had itself been a massive roofed building, comparable with the 'council houses' of certain Native American communities (Wainwright and Longworth 1971.232). However, subsequent investigation of some even larger timber circles has demonstrated that they were simply too big to be roofed, and the same was probably true of the Southern Circle ( $D a$ vid et al. 2004) (see Fig. 13 for the probable appearance of the Southern Circle in its second phase). While there were indeed two phases of construction, our re-excavation in 2005-6 demonstrated that some of what had been identified as postholes of the first phase were actually integral to the second, standing on either side of individual larger posts, and perhaps supporting sections of fencing or shuttering. The structure thereby defined establishes a secluded inner space within the circle, comparable with the innermost area of Stonehenge. Tellingly, this structure respects the spiral entrance passage to the secondphase circle. The implication of this is that the first phase circle was comparatively modest, composed of four main posts, surrounded by a single post-ring, attached to an avenue and façade. This would make it very similar to both the Northern Circle, and the 
structures excavated south of Woodhenge (see above).

Another issue addressed through re-investigating the Southern Circle was that of deposition. Wainwright's original interpretation for the concentration of finds in the upper parts of the post-hole fills was that, within the roofed building, sherds of pottery, animal bones and other objects had been placed as offerings at the bases of the timber uprights. When the latter had rotted out, the objects fell into what he referred to as 'weathering cones' (Wainwright and Longworth 1971.24-5). These he argued to have been formed by the erosion of the post-packing, following the decay of the posts. However, this interpretation was open to question. If we accept that the structure was unroofed, it is hard to see how pottery sherds and animal bones could have survived on the surface for some decades in an unabraded state, before falling into the weathering cones. In all of the post-holes excavated in 2005-6, it was clear that the so-called 'weathering cones' were actually conical re-cuts, dug after the posts had rotted out (see Fig. 14).

Inside these re-cut features, deposits of flints and animal bones had clearly been placed, or at least dumped, rather than having fallen haphazardly into eroding post-pipes. Animal bone predominated, but flint occurred as clusters of waste, often higher in the fill (Thomas 2007.149). In all cases, pottery sherds were found almost exclusively in the upper part of the re-cut fill. This suggests a pattern in which sherds were being carefully placed into the tops of the re-cuts following the more summary deposition of flint and bone. It is clear, though, that our excavated area, located opposite the entrance to the circle, produced far smaller quantities of cultural material than the postholes facing toward the avenue and the river, dug in 1967. In other words, the densities of objects placed in each posthole reflected the individual importance of each feature. If this material had been deposited in features that were cut after the posts had rotted out, it must have post-dated the construction and initial use of the circle by

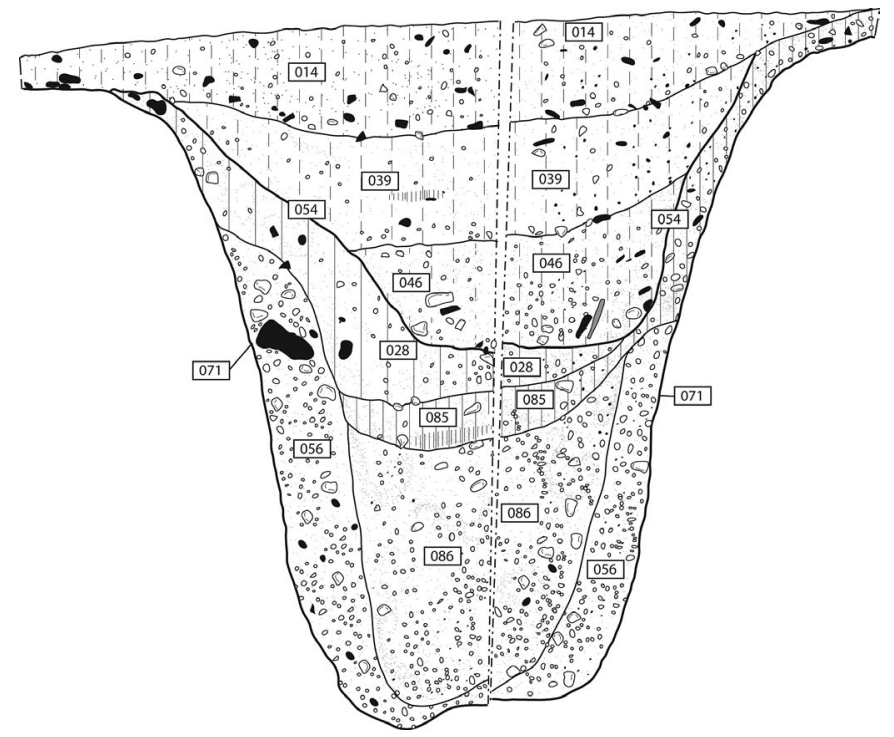

Fig. 14. Section of post-hole 071 in the Southern Circle, showing re-cut pit in the upper fill (drawing: Julia Roberts). 


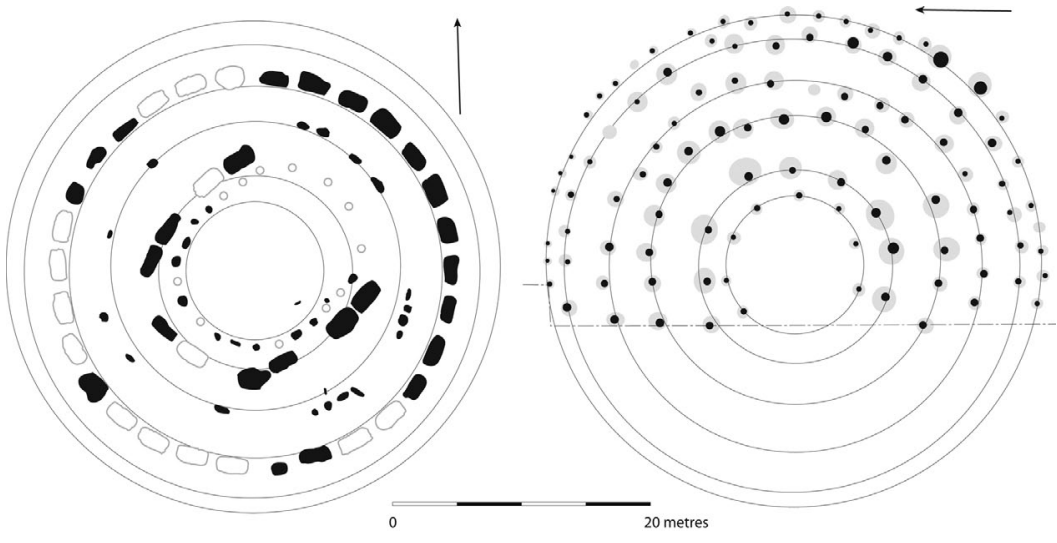

Fig. 15. Comparison of the plans of the Stonehenge stone settings and the Southern Circle (drawing: Julian Thomas).

was then one of collapsed timbers, slumped postholes, and memories that were brought to mind through acts of deposition. So this was now an 'architecture of memory', commemorated in its absence.

We have noted that the discovery of the roadway demonstrates that Durrington Walls and Stonehenge are effectively parts of a single structure linked by the two avenues and the river. This challenges some of our implicit expectations of monumentality, for rather than being a cultural imposition onto a natural landscape, the Stonehenge-Durrington complex threads together built elements and topography. We might argue that both the Stonehenge and the Durrington avenues were conceptually indistinguishable from the river, and that the two henge enclosures were linked by flows and movements of various kinds. This encourages us to consider the rela- tionship between the Southern Circle and the Stonehenge stone settings at each end of this passage. We might see them as complementary structures: while composed of stone and timber respectively, they are remarkably similar in plan (Fig. 15). The principal sarsen and bluestone settings at Stonehenge have much the same diameters as the four inner rings at Durrington, and similar units of measurement appear to have been used in laying them out (Chamberlain and Parker Pearson 2007). Significantly, the interiors of both structures are much the same size, and would have admitted the same number of people. Moreover, we have seen that the Southern Circle may have had a secluded inner space comparable with the Stonehenge sarsen 'horseshoe', while a geophysical survey of the unexcavated portion of the Southern Circle undertaken in 2006 suggests some elements of the Southern Circle may be oval rather than truly circular. It is highly likely that some relationship of mirroring or mimicry existed between the Durrington Southern Circle and the stone settings at Stonehenge.

Further to the west again, on a terrace overlooking the Southern Circle and the eastern entrance, a group of at least six penannular enclosures have been revealed by geophysical survey. While these

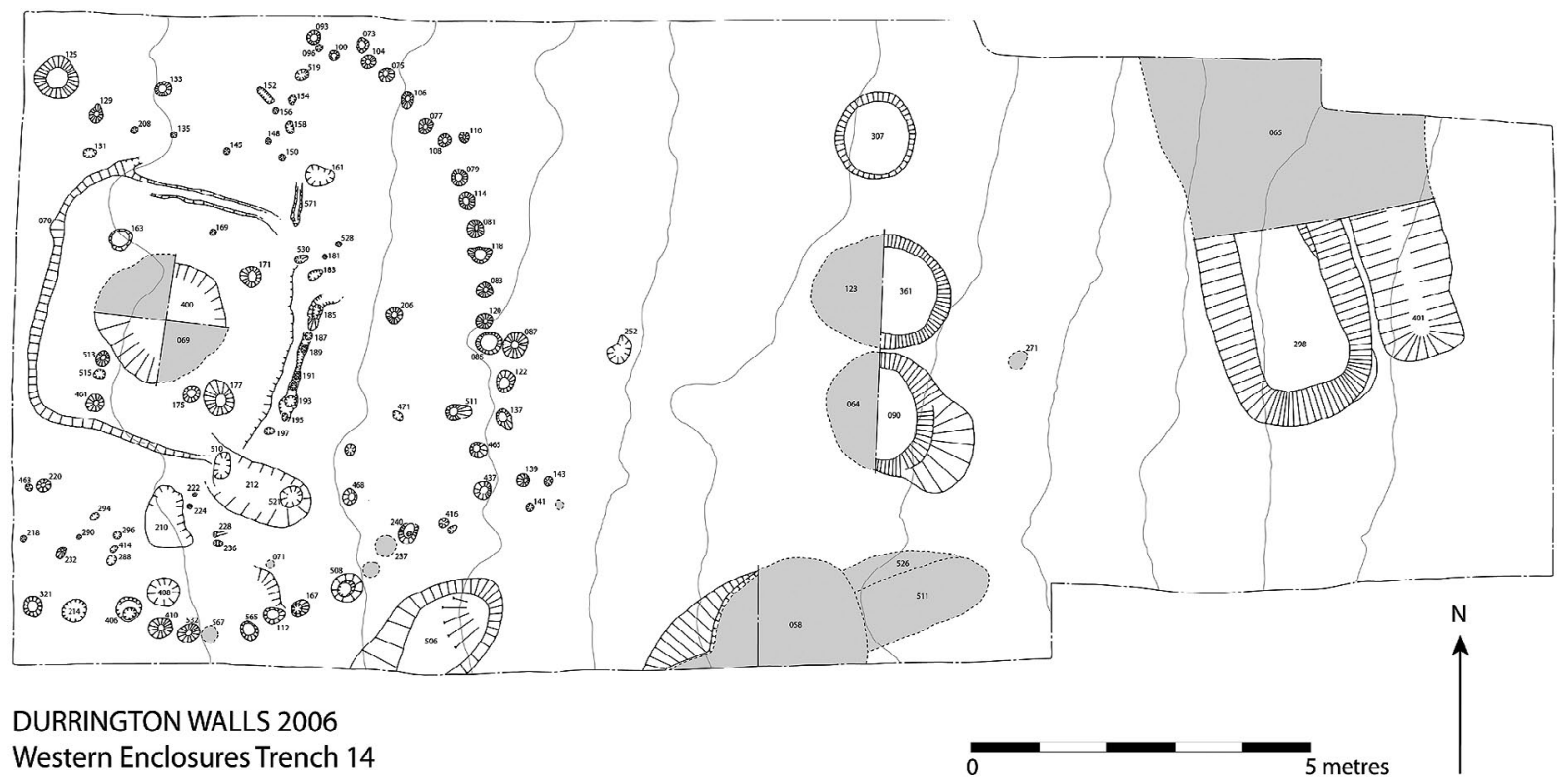

Fig. 16. Plan of enclosed building (Trench 14), Western Enclosures, Durrington Walls 2006 (drawing: Julian Thomas). 
were reasonably expected to have enclosed burials or more timber circles, the two that were excavated actually contained small buildings not dissimilar to those at the eastern entrance (Thomas 2007.152). However, in each case the building was enclosed inside a timber palisade, while each 'house' had four post-holes, presumably roof-supports, surrounding the central hearth (Fig. 16). These were not present in the houses at the eastern entrance. The building in the larger of the

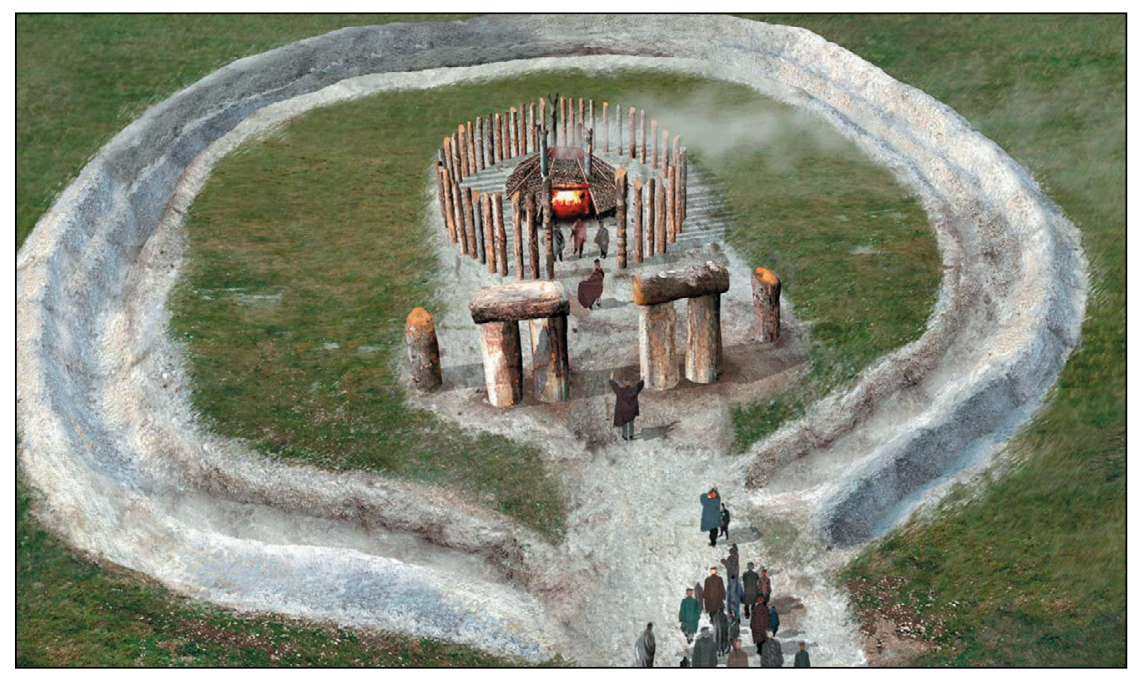

Fig. 17. Reconstruction of enclosed building (Trench 14), Western Enclosures, Durrington Walls (image: Aaron Watson). two ring-ditches investigated also had a façade of huge posts, so closely-set that they may have represented the equivalent in timber of the Stonehenge trilithons (see Fig. 17). Both buildings appear to have been kept clean in comparison with the filthy houses at the eastern entrance, and the larger one had a pit immediately outside the entrance to the palisade containing distarticulated animal bones and abraded pottery that may have been accumulated in the course of cleaning up.

So were these buildings inside the Western Enclosures elite residences, or were they shrines or culthouses? The key to this question may lie in their similarity with the first phase of the Southern Circle, with the Northern Circle, and with the structures investigated south of Woodhenge. Here, the familiar architecture of the Grooved Ware house was elaborated upon, and elements that were more usually found in monumental contexts were added to draw attention to the separation between the small enclosed space of the building and the outside world, including the more obviously domestic dwellings. Significantly, Richards (1993) has described a similar process in Neolithic Orkney, in which the modular form of the house found echoes in the layout of chambered tombs and henge monuments. At an early stage, the natural amphitheatre of Durrington Walls was occupied by a series of structures that developed a single basic plan in different ways, pro- viding spaces for dwelling and for ritual. Only later did the more complex concentric architecture of the Southern Circle and Woodhenge develop, at a time when the former came to be physically linked to Stonehenge in a new and grand design that drew the entire landscape together. Recognising this, however, depends on acknowledging the long and complex histories of place that the Stonehenge Riverside Project has revealed.

We thank our colleagues on the Stonehenge Riverside Project, particularly Umberto Albarella, Mike Allen, Mark Dover, Charly French, Karen Godden, Dave Robinson, the site supervisors (Dave Aspden, Ian Heath, Neil Morris, Bob Nunn, Becca Pullen, Jim Rylett, Dave Shaw, Anne Teather), the outreach team and the many students and volunteers who have made this work such a success so far. We also thank Amanda Chadburn, Richard Osgood, Mike Pitts and Julian Richards for their advice and support. Funding for the SRP was provided by the Arts and Humanities Research Council, the British Academy, English Heritage, the McDonald Institute, the National Geographic Society, the Prehistoric Society (who awarded it the Bob Smith Prize), the Royal Archaeological Institute and the Society of Antiquaries. We thank the Rawlins family, the National Trust, Wiltshire County Council and the Ministry of Defence for permission to excavate on their land. 


\section{REFERENCES}

ALBARELLA U. and SERJEANTSON D. 2002. A passion for pork: meat consumption at the British Late Neolithic site of Durrington Walls. In P. Miracle and N. Milner (eds.), Consuming Passions and Patterns of Consumption. McDonald Institute. Cambridge: 33-49.

ATKINSON R. J. C. 1956. Stonehenge. Hamish Hamilton. London.

BARRETT J. C. 1994. Fragments from Antiquity. Blackwell. Oxford.

BENDER B. 1998. Stonehenge: Making Space. Berg. London.

BRADLEY R. J. 1998. The Significance of Monuments. Routledge. London.

CHAMBERLAIN A. and PARKER PEARSON M. 2007. Units of measurement in Late Neolithic southern Britain. In M. Larsson and M. Parker Pearson (eds.), From Stonehenge to the Baltic. British Archaeological Reports. International Series 1692. Archaeopress, Oxford: 169-74.

CHILDE V. G. 1931. Skara Brae: A Pictish Village in Orkney. Kegan Paul. London.

CHILDE V. G. and GRANT W. G. 1947. A Stone-Age settlement at the Braes of Rinyo, Rousay, Orkney (Second Report). Proceedings of the Society of Antiquaries of Scotland 81: 16-42.

CHIPPINDALE C. 1990 (ed.). Who Owns Stonehenge? Batsford. London.

CHRISTIE P. 1963. The Stonehenge Cursus. Wiltshire Archaeological Magazine 58: 370-382.

CLEAL R., WALKER K. and MONTAGUE R. 1995. Stonehenge in its Landscape: Twentieth Century Excavations. English Heritage. London.

CUNNINGTON M. E. 1929. Woodhenge. Simpson. Devizes.

DARVILL T. C. 2005. Stonehenge World Heritage Site: An Archaeological Research Framework. English Heritage. London.

DAVID A., COLE M., HORSLEY T., LINFORD N., LINFORD P. and MARTIN L. 2004. A rival to Stonehenge? Geophysical survey at Stanton Drew, England. Antiquity 78: 341-358.

GARROW D. 2006. Pits, Settlement and Deposition during the Neolithic and Early Bronze Age in East Anglia. British Archaeological Reports. British Series 414, Archaeopress. Oxford.
HARRIS T. 2007. A303 Stonehenge improvement scheme: statement by the Parliamentary Under-Secretary for Transport. http://www.dft.gov.uk/press/speechesstatements/ statements/a303. Consulted $15^{\text {th }}$ March 2008.

HOARE R. C. 1810. The Ancient History of Wiltshire. William Miller. London.

MCOMISH D., FIELD D. and BROWN G. 2002. The Field Archaeology of the Salisbury Plain Training Area. English Heritage. London.

PARKER PEARSON M. 2007. The Stonehenge Riverside Project: excavations at the east entrance of Durrington Walls. In M. Larsson and M. Parker Pearson (eds.), From Stonehenge to the Baltic, British Archaeological Reports. International Series 1692. Archaeopress, Oxford: 12544.

PARKER PEARSON M. and RAMILSONINA 1998. Stonehenge for the ancestors: the stones pass on the message. Antiquity 72: 308-26.

PARKER PEARSON M., CLEAL R., MARSHALL P., NEEDHAM S., POLLARD J., RICHARDS C., RUGGLES C., SHERIDAN A., THOMAS J., TILLEY C., WELHAM K., CHAMBERLAIN A., CHENERY C., EVANS J., KNÜSEL C., LINFORD N., MARTIN L., MONTGOMERY J., PAYNE A. and RICHARDS M. 2007. The age of Stonehenge. Antiquity 81: 617-39.

PITTS M. 2001. Hengeworld. Arrow Books. London.

POLLARD J. 1995. Inscribing space: formal deposition at the later Neolithic monument of Woodhenge, Wiltshire. Proceedings of the Prehistoric Society 61: 137-56.

2001. The aesthetics of depositional practice. World Archaeology 33: 315-33.

POLLARD J. and ROBINSON D. 2007. A return to Woodhenge: the results and implications of the 2006 excavations. In M. Larsson and M. Parker Pearson (eds.), From Stonehenge to the Baltic. British Archaeological Reports. International Series 1692. Archaeopress, Oxford: 15968 .

RICHARDS C. C. 1993. Monumental choreography: architecture and spatial representation in late Neolithic Orkney. In C. Tilley (ed.), Interpretative Archaeology. Berg. London: 143-78.

2004. A choreography of construction: monuments, mobilization and social organization in Neolithic Orkney. In J. Cherry, C. Scarre and S. Shennan (eds.), $E x$ plaining Social Change: Studies in Honour of Colin Renfrew. McDonald Institute. Cambridge: 103-30. 
RICHARDS C. (ed.) 2003. Dwelling among the Monuments: The Neolithic Village of Barnhouse, Maeshowe Passage Grave and Surrounding Monuments at Stenness, Orkney. McDonald Institute for Archaeological Research. Cambridge.

RICHARDS C. C. and THOMAS J. S. 1984. Ritual activity and structured deposition in later Neolithic Wessex. In R. Bradley and J. Gardiner (eds.), Neolithic Studies. British Archaeological Reports. British Series 133. Oxford: 189218.

RICHARDS J. 1990. The Stonehenge Environs Project. London: English Heritage.

ROWLEY-CONWY P. 2004. How the west was lost: a reconsideration of agricultural origins in Britain, Ireland, and southern Scandinavia. Current Anthropology 45: 83113. Supplement.

STONE E. H. 1924. The Stones of Stonehenge. Robert Scott. London.

STONE J. F. S. 1947. The Stonehenge Cursus and its affinities. Archaeological Journal 104: 7-19.

STONE J. F. S., PIGGOTT S. and BOOTH A. 1954. Durrington Walls, Wiltshire: recent excavations at a ceremonial site of the early second millennium BC. Antiquaries Journal 34: 155-77.

THOMAS J. S. 2004. Materiality and traditions of practice in Neolithic south-west Scotland. In V. Cummings and C. Fowler (eds.), The Neolithic of the Irish Sea: Materiality and Traditions of Practice. Oxbow. Oxford: 174-84.
2007. The internal features at Durrington Walls: investigations in the Southern Circle and western Enclosures, 2005-6. In M. Larsson and M. Parker Pearson (eds.), From Stonehenge to the Baltic. Oxford: British Archaeological Reports. International Series 1692. Archaeopress. Oxford: 145-58.

THOMAS J., PARKER PEARSON M., POLLARD J., RICHARDS C., TILLEY C. and WELHAM K. 2008. The date of the Greater Stonehenge Cursus. Antiquity 82: 1-14.

TILLEY C. 1994. A Phenomenology of Landscape. London. Berg.

TILLEY C., RICHARDS C., BENNETT W. and FIELD D. 2007. Stonehenge - its landscape and architecture: a re-analysis. In M. Larsson and M. Parker Pearson (eds.), From Stonehenge to the Baltic. British Archaeological Reports. International Series 1692. Archaeopress, Oxford: 183-204.

WAINWRIGHT G. J. 1989. The Henge Monuments. Thames and Hudson. London.

WAINWRIGHT G. J. and LONGWORTH I. H. 1971. Durrington Walls: excavations 1966-1968. Society of Antiquaries. London.

WHITTLE A. 2003 The Archaeology of People: Dimensions of Neolithic Life. Routledge. London.

WORTHINGTON A. 2004. Stonehenge: Celebration and Subversion. Alternative Albion. Loughborough.

(ed.) 2005. The Battle of the Beanfield. Enabler Publications. Teignmouth. 